\title{
Stem cells in toxicity testing
}

\author{
J. D. Stewart • H. M. Bolt
}

Published online: 21 January 2011

(C) Springer-Verlag 2011

Recently, stem cells have attracted much interest as tools for toxicity testing (Heng et al. 2009; Snykers et al. 2007; Aurich et al. 2007; Ruhnke et al. 2005). Therefore, the editors are pleased that Prof. Anna Wobus from the Leibniz Institute in Gatersleben and Dr. Peter Löser from the Robert-Koch-Institute in Berlin have contributed a comprehensive review about the present state and future perspectives of stem cells in toxicology research to this issue of our journal (Wobus and Löser 2011; this issue).

Principally, two approaches have been used in this field of research. Stem cells in culture are stimulated to undergo a certain developmental process, for example to recapitulate a certain phase of embryonic development. Then by addition of test compounds, it can be analyzed whether the developmental process is compromised. This strategy has been successfully applied to identify a number of teratogens (Eckardt and Stahlmann 2010). A large EU-consortium, ESNATS, currently uses this approach to establish assays for developmental neurotoxicity. For this purpose, human embryonic stem cells are stimulated to undergo early stages of neurodifferentiation. A second approach aims at generating mature cells, such as hepatocytes, cardiomyocytes or neurons, which could then be used as target cells for "adult" toxicity testing. In principle, this approach is attractive as it could lead to an unlimited supply of primary human cells. A few years ago, there was a hype

J. D. Stewart $(\bowtie) \cdot$ H. M. Bolt

Leibniz Institut für Arbeitsforschung an der TU Dortmund, Leibniz Research Centre for Working Environment and Human Factors (IfADo), Ardeystrasse 67,

44139 Dortmund, Germany

e-mail: stewart@ifado.de regarding studies claiming that they could generate functional hepatocytes from stem cells (review: Hengstler et al. 2005). For example, Schwartz et al. reported that progenitor cells from bone marrow differentiate into "functional hepatocyte-like cells" (Schwartz et al. 2002), while Jang et al. claimed that "hematopoietic stem cells convert into liver cells within days without fusion" (Jang et al. 2004). However, it has become clear that these were overoptimistic interpretations (Hengstler et al. 2005; Brulport et al. 2007; Hewitt et al. 2007). Direct comparison of the latter stem cell-derived "hepatocyte-like cells" with primary hepatocytes has shown that huge differences remain; therefore, replacement of primary by stem cell-derived hepatocytes is not yet possible. Today, primary hepatocytes are still the most reliable and most frequently used in vitro tool for studies of drug metabolism, enzyme induction and hepatotoxicity (Hewitt et al. 2007; Schumann et al. 2009; Hengstler et al. 2009; Schug et al. 2008; Godoy et al. 2009; Kafert-Kasting et al. 2006; Ruhnke et al. 2005; Ringel et al. 2005; Wang et al. 2009; Ostrowska et al. 2009). Whereas it remains a long way until stem cell-derived hepatocytes can be used for routine applications in Toxicology. The current state of the art article of Anna Wobus and Peter Löser is a must-read for everybody interested in stem cell applications in Pharmacology and Toxicology.

\section{References}

Aurich I, Mueller LP, Aurich H, Luetzkendorf J, Tisljar K, Dollinger MM, Schormann W, Walldorf J, Hengstler JG, Fleig WE, Christ B (2007) Functional Integration of hepatocytes derived from human mesenchymal stem cells into. Gut 56:405-415

Brulport M, Schormann W, Bauer A, Hermes M, Eisner C, Hammersen FJ, Beerheide W, Spitkovsky D, Härtig W, Nussler A, Horn LC, Edelmann J, Pelz-Ackermann O, Petersen J, Kamprad M, 
von Mach M, Lupp A, Zulewski H, Hengstler JG (2007) Pate of extrahepatic human stem and precursor cells after transplantation into mouse livers. Hepatology 46:861-870

Eckardt K, Stahlmann R (2010) Use of two validated in vitro tests to assess the embryotoxic potential of mycophenolic acid. Arch Toxicol 84:37-43

Godoy P, Hengstler JG, Ilkavets I, Meyer C, Bachmann A, Müller A, Tuschl G, Mueller SO, Dooley S (2009) Extracellular matric modulates sensitivity of hepatocytes to fibroblastoid dedifferentiation and transforming growth factor beta-induced apoptosis. Hepatology 49:2031-2043

Heng BC, Richards M, Shu Y, Gribbon P (2009) Induced pluripotent stem cells: a new tool for toxicology screening? Arch Toxicol 83:641-644

Hengstler JG, Brulport M, Schormann W, Bauer A, Hermes M, Nussler AK, Fandrich F, Ruhnke M, Ungefroren H, Griffin L, Bockamp E, Oesch F, von Mach MA (2005) Generation of human hepatocytes by stem cell technology: definition of the hepatocvte. Expert Opin Drug Metab Toxicol 1:61-74

Hengstler JG, Godoy P, Bolt HM (2009) The dilemma of cultivated hepatocytes. Arch Toxicol 83:101-103

Hewitt NJ, Lechön MJ, Houston JB, Hallifax D, Brown HS, Maurel P, Kenna JG, Gustavsson L, Lohmann C, Skonberg C, Guillouzo A, Tuschl G, Li AP, LeCluyse E, Groothuis GM, Hengstler JG (2007) Primary hepatocytes: current understanding of the regulation of metabolic enzymes and transporter proteins, and pharmaceutical practice for the use of hepatocytes in metabolism, enzyme induction, transporter, clearance, and hepatotoxicity studies. Drug Metab Rev 39:159-234

Jang YY, Collector MI, Baylin SBS, Diehl AM, Sharkis SJ (2004) Hematopoietic stem cells convert into liver cells within days without fusion. Nat Cell Biol 6:532-539

Kafert-Kasting S, Alexandrova K, Barthold M, Laube B, Friedrich G, Arseniev L, Hengstler JG (2006) Enzyme induction in cryopreserved human hepatocyte cultures. Toxicology 220:117-125

Ostrowska A, Gu K, Bode DC, Van Buskirk RG (2009) Hypothermie storage of isolated human hepatocytes: a comparison between
University of Wisconsin Solution and a hypothermosol platform. Arch Toxicol 83:493-502

Ringel M, von Mach MA, Santos R, Feilen PJ, Brulport M, Hermes M, Bauer AW, Schormann W, Tanner B, Schön MR, Oesch F, Hengstler JG (2005) Hepatocytes cultured in alginate microspheres: an optimized technique to study enzyme induction. Toxicology 206:153-167

Ruhnke M, Ungefroren H, Nussler A, Martin F, Brulport M, Schormann W, Hengstler JG, Klapper W, Ulrichs K, Hutchinson JA, Soria B, Parwaresch RM, Heeckt P, Kremer B, Fandrich F (2005) Differentiation of in vitro-modified human peripheral blood monocytes into hepatocyte-like and pancreatic islet-like ceils. Gastroenterology 128:1774-1786

Schug M, Heise T, Bauer A, Storm D, Blaszkewicz M, Bedawy E, Brulport M, Geppert B, Hermes M, Föllmann W, Rapp K, Maccoux L, Schormann W, Appel KE, Oberemm A, GundertRemy U, Hengstler JG (2008) Primary rat hepatocytes as in vitro system for gene expression studies: comparison of sandwich, Matrigel and 2D cultures. Arch Toxicol 82:923-931

Schumann A, Bauer A, Hermes M, Gilbert M, Hengstler JG, Wilhelm C (2009) A rapid and easy to handle thermoluminescence based technique for evaluation of carbon tetrachloride-induced oxidative stress on rat hepatocytes. Arch Toxicol 83:709-720

Schwartz REE, Reyes M, Koodie L et al (2002) Multipotent adult progenitor cells from bone marrow differentiate into functional hepatocyte-like cells. J Clin Invest 109:1291-1302

Snykers S, Vinken M, Rogiers V, Vanhaecke T (2007) Differential role of epigenetic modulators in malignant and normal stem cells: a novel tool in preclinical in vitro toxicology and clinical therapy. Arch Toxicol 81:533-544

Wang Y, Xu Y, Wang H, Xue P, Li X, Li B, Zheng Q, Sun G (2009) Arsenic induces mitochondria-dependent apoptosis by reactive oxygen species generation rather than glutathione depletion in Chanq human hepatocytes. Arch Toxicol 83:899-908

Wobus AM, Löser P (2011) Present state and future perspectives of using pluripotent stem cells in toxicology research. Arch Toxicol (online first) 